\title{
Reality and perspectives of a model for the population that obtains its income with the use of an animal-drawn vehicle in the city of Bogota
}

\author{
Sánchez Aparicio, Ismael Fernando., Romero Villalobos, Oswaldo Alberto. \\ Universidad Distrital Francisco José de Caldas, Bogotá, Colombia
}

\begin{abstract}
This paper analyzes the structure of the data collected in the population dependent or receives its revenues in the use of animal-drawn vehicle, to extract an economic model for the development of this activity (which is currently done with these vehicles and is unbusinesslike) introducing formal parameters, as well as replacement of the vehicle analyzes the development of this activity in this population.
\end{abstract}

Keywords - mobility, animal-drawn vehicles, traffic and transport, Management Models.

\section{INTRODUCTION}

$\mathrm{T}$ he District University in partnership with the District Department of Transportation developed the project "Technical, legal, financial and social withdrawal project drawn vehicles - Development of socioeconomic characteristics of the population of wheelwrights (VTA) in the city of Bogotá, including proposed scenarios viable and sustainable economic projects that replace and/ or technify animal-drawn vehicle (ATV) - Phase One" within the project results were compiled economic data how dependent people or receive their income from the use of animal-drawn vehicle, these data allowed, once processed, extracting an economic model for the development of this activity, yes, without neglecting the activity currently being undertaken with these vehicles is unbusinesslike, and it is necessary to begin entering parameters formalization of this activity, and it is also necessary to think of replacing the vehicle that is currently used for the development of this activity in this population.

\section{MODEL FEATURES}

\section{A. Population profile (VTA)}

According to the results of the census conducted within the scope of the project and correspondence analysis conducted, it was concluded that the population of wheelwrights (VTA) is median age (35 years), with a level of education that is among the final years of primary school and early high school, living primarily in family, which has been established by cohabitation and share your home with children, siblings and parents.

The wheelwright (VTA) has chosen activity to the extent that his inner circle develops the same activity and in many cases, family members are jointly involved in the development of the tasks associated with the management of the wagon.

Those who engage in this activity are owners of his wagon and horses have it and not only a single set, which kept in proper condition. They live primarily in rented house and have access to basic services of water and energy, but do not have access to natural gas. Managing your garbage is done by the utility company, which shows the coverage of these services by district entities.

They usually work 8 to 12 hours or so and they do between Monday and Friday, but work on Saturday's noon. The wheelwrights made between 1 and 2 daily trips and their activity is directed mainly to recycling (glass, paper, plastic and metal mostly).

\section{B. Current function of expenses (FAE)}

Once the wheelwrights population profile (VTA), we found that this population group to perform an informal activity, manages its economy in the same way, though it was established that despite this, this population based his scheme of aggregate expenditures on two parameters, namely, home maintenance costs and maintenance of animal-drawn vehicle on one hand the cost of upkeep of the home, are part of the function of expenses, because the administrative, planning logistics and marketing strategies are developed within the family, where family members, act as administrators and managers in this task, so the costs of maintenance of the home are part of the expenditure function.

On the other hand, despite having no formal, expenditures for home maintenance costs resemble those of a home at any lower layer 3 and its calculation is based on:

Public services (SP), financing of housing ownership (AV), Food and cleanliness (AA), Education and Entertainment (EE) and Health and other minor expenses (SG). With the foregoing the calculation represented:

$$
S O_{n}=S P_{n}+A V_{n}+A A_{n}+E E_{n}+S G_{n} n=1,2,3 \text {, ete }
$$

For the schema of the function and its components, you can see that this equation tends to be constant, since a home tends to stabilize and maintain their support costs at a fixed interval of low variability, this situation is familiar to the road population, however in certain periods or the result of 
uncontrolled events, this equation may have variations from one period to another, in circumstances such as new household members, housing changes, external situations, etc.., so is must set the value of the equation to the conditions of the period, for the calculation of the function.

Moreover, within the expenditure function can find another cost parameter, and this is the maintenance of animal-drawn vehicle (MVTA), which as its name suggests answers to the calculation of the expenses incurred by animal-drawn vehicle, but unlike the upkeep of the home to calculate this equation, vary according to the use of animal-drawn vehicle in the period, because, for the calculation takes the following variables: Rent a manger + parking (APP), wagon rent + horse (ACE), horse maintenance expenses (GME) and expenses of the wagon (GMC), and the calculation is:

$$
W T A_{n}=A P P_{n}+A C E_{n}+G M E_{n}+G M C_{n}, n=1,2,3 \ldots \text { ath }
$$

Equation MVTA $_{n}$, can be divided into two parts viz, the first of these variables is associated with APP and ACE, which tend to assume positive values constant indifferent of using animaldrawn vehicle, ie tend to assume the same value period becoming a constant period at different times, but still and knowing this, these variables may fluctuate permanent possibilities event such as: horse change, change of parking, etc.., on the other hand have cost variables GMC and GME, unlike the first, these variables, as they tend to vary in relation to the use of animal-drawn vehicle in the period, since its value responds to the calculation of variables associated with the use of animal-drawn vehicle, so such as the fittings are costs to be incurred in the extent to which greater use of horses, the animal disease can become the occasion of contact with other horses or sites stay low hygiene, is more prone to traffic accidents in the extent to which the vehicle share the road with other vehicles, etc.

Having stated the above, the function of expenses $f(F A E)$, responds to the sum of the variables discussed above, adding the two groups given above, we can say that $f(F A E)$ it is equal to the sum of $S O_{n}$ and $M V T A_{n}$, thus:

$$
f(F A E)=S O_{n}+M_{V T A}, n=1,2,3 \ldots \text { etc }
$$

\section{Current Income Function (FIA)}

For the calculation of the income is part of the way the wheelwrights carry out their work, ie, what was found, once the information was collected, is that this population operates in an informal way, that its main activity is the collection of materials for recycling, that in addition to this recycling, also dedicated to the transport of debris or construction material, but despite this, payment is due on sale in gathering place of the weight in kilos of transported material, so as FIA current income due to the amount of trips transporting different types of materials on the day $\mathrm{x}$ the number of days worked in the period, being affected this relationship by the number of hours that a wheelwrights works on an ordinary day, the income also vary according to the mix of materials animal drawn vehicle transport to the collection center, the results of the field work showed that the main materials transported by the population (VTA) are: Glass (VI), paper (PA), Plastic (PLA) and metal (ME) for the most part, also found that some of them and in some specific days a week, can transport crates (GU), rubble (ES) or other not so frequently, the above revenue function, is given by the sum of the different materials in kilos put into the collection center or place of sale, multiplied by the sales price of the same:

$$
f(F L A)=\sum_{i=1}^{n} P_{i} x M T_{i}
$$

In equation $P$ is the selling price per kilo material and $M T$ is the type of material transported, on the other hand, this function has a restricted income, which refers to the ability of the animal-drawn vehicle in kilograms to transport material, as well as the carrying capacity of the wagon is associated with the ability to have the animal shot in the fieldwork, it was found that the majority of animals used in this work are light horses (under $650 \mathrm{~kg}$ ) and heavy, and although not common, were also found mules and other animals for these studies, we also found that animals for this work are mostly race called creoles and in a few cases were found mixed breeds animals as the percheron and Creole, apart from this, the capacity of these animals will vary according to the weight of the animal, the size of it, race horse over the animal, on the other hand, we also found that the cart, also influences the total load capacity, details such as the type of tires used, type mechanism in which the tires are mounted (bearings, etc.), the material of the structure and the slab; with the foregoing, the revenue function is:

$$
f(F L A)=\sum_{i=1}^{n} P_{i} x M T_{i}
$$

Subject to:

$$
\sum_{\mathrm{i}=1}^{n} M T_{\mathrm{i}} \leq(k x P E)-(c x P C)
$$

Where ${ }^{k}$ is the coefficient associated with the load you can drag the equine, $P E$ equine weight, ${ }^{c}$ is the coefficient of the structure of the wagon (This will vary according to the maintenance of the wagon and supplies it) and finally $P C$ the weight of the wagon. 
Moreover wheelwrights population, despite developing its work in the informal, is no stranger to market behavior and the conditions thereof, so as the price of kilo of material at the point of collection will vary according to demand the same experience in the period, so as to offer more the price will tend to fall and less supply of the same the effect is opposite, that is, the price will tend to rise, the equation for this situation is first degree (linear) and can be generally represented as follows:

$$
P=e x M T+P_{\text {min }}
$$

Where the price will vary according to ${ }^{e}$ who is modulus of elasticity, this is multiplied by the amount of material to sell, the equation is complemented with a minimum price or zero price of units, the behavior of the function vary according to the value of elasticity, which determines the slope of the same and the minimum price, the graph of the function behaves as in Figure 1, where the slope of the linear function defined by the falling price of the material with respect to the higher volume thereof.

Returning to the role of income and considering the variations with respect to prices previously explained, the new function of income will be:

$$
f(F L A)=\sum_{\mathrm{i}=1}^{n}\left(e x M T+P_{\min }\right)_{\mathrm{i}} x M T_{\mathrm{i}}
$$

Subject to:

$$
\sum_{\mathrm{i}=1}^{n} M T_{\mathrm{i}} \leq(k \times P E)-(c \times P C)
$$

Operating, finally revenue function is:

$$
f(F L A)=\sum_{\mathrm{i}=1}^{n}\left(e_{\mathrm{i}} x M T_{\mathrm{i}}^{2}\right)+\left(P_{\min \mathrm{i}} x M T_{\mathrm{i}}\right)
$$

Subject to:

$$
\sum_{\mathrm{i}=1}^{n} M T_{\mathrm{i}} \leq(k \times P E)-(c \times P C)
$$

But the market volume is finally defined by all potential revenue to be gained by selling materials and are tied to the demand function, this says that the market will have a maximum value, this maximum is the highest possible income that given material could produce.

For this value, the point of maximum revenue, would derive revenue function. This concept is called Marginal Revenue and the point of maximum income will be given when the value of the marginal revenue function is equal to 0 (zero), that is:

$$
\frac{d f(F L A)}{d M T}=\sum_{\mathrm{i}=1}^{n} 2 e_{\mathrm{i}} M T_{\mathrm{i}}+P_{\min i}
$$

Where the value of the function is zero, find the maximum amount of material that can be sold without causing a decline in revenue.

\section{Cash Flow Model}

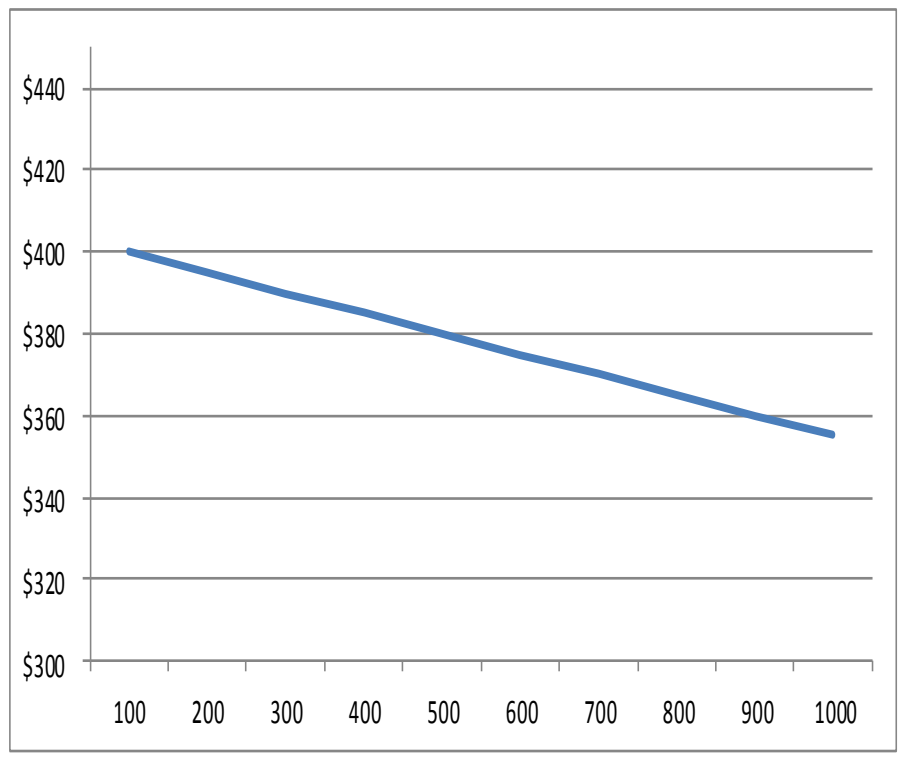

Fig 1. Sample materials demand function for A

Based on the income and expenses, we propose a cash flow model for recycling activity developed by the population of VTA wheelwrights, in this model is considered SO, MVTA as part of FIA expenditures and revenues as part of this is illustrated in Table 1.

This enclosure leads us to define the population of wheelwrights and to the activity as such the equation that helps us to establish the sustainability of the business and that is:

$$
\frac{\left(f(F I A)_{n-1}-\left(S O_{n-1}+M V T A_{n-1}\right)\right)+f(F I A)_{n}}{S O_{n+1}+M V T A_{n+1}}
$$

Where should ensure that the income of the period plus the remaining amount of prior period do not exceed the amount of income in the period under review, according to information collected in the field and testimonials from community members themselves, is some periods sustainability of the activity tends to be below the minimum support value, a situation that forces people to wheelwrights to use strategies such as reducing maintenance costs of home sale or disposition of goods, loans informally with moneylenders, etc. 
TABLE 1

CASH FLOW MODEL FOR POPULATION OF WHEELWRIGHTS (VTA)

\begin{tabular}{|c|c|c|c|}
\hline & Month $\mathrm{n}$ & Month $n+1$ & Month $n+2$ \\
\hline Income & $f(F L A)_{n}$ & $f(\text { FIA })_{n+1}$ & $f(F L A)_{n+2}$ \\
\hline Functional Expenses & $s o_{n}$ & $S O_{n+1}$ & $\mathrm{SO}_{\mathrm{n}+2}$ \\
\hline Operating Expenses & $M V T A_{n}$ & $M V T A_{n+1}$ & $\operatorname{MVTA}_{n+2}$ \\
\hline Total expenses & $S O_{n}+M V T A_{n}$ & $S O_{n+1}+M V T A_{n+1}$ & $S O_{n+2}+M V T A_{n+2}$ \\
\hline Cash & $f(F l A)_{n}-\left(S O_{n}+M V T A_{n}\right)$ & $f(F L A)_{n+1}-\left(S O_{n+1}+M_{n T A_{n+1}}\right)$ & $f(F I A)_{n+2}-\left(S O_{n+2}+M V T A_{n+2}\right)$ \\
\hline
\end{tabular}

\section{E. Management Model}

The population of wheelwrights uses a management model based on the immediate response to emerging needs, that is, the administrative management of money management is done in an informal way, no records of any kind logistics management is very poor or non-there since the horse-drawn vehicle begins the workday without fixed route plan, on the other hand the work of marketing and product advertising is not because the carters client is always the same and if generated these changes do not correspond to planning but rather for casual events, management of portfolio (by the way of work) is nonexistent and not allow credit sales, no inventory and manage transformation processes do not.

Therefore, management model of these business units is reduced to a daily revenue management, for these his two cost parameters: one for family and one for the vehicle, the savings are nonexistent, so no money reserves for contingencies and for modernization of the team, or for innovation or development.

The current management model that caused the population (VTA), carrying out business at a disadvantage with the rest of the population is engaged in the transportation of material, gradually forcing them to transform their business, in addition to this the animal-drawn vehicles are causing various problems such as traffic difficulties (low travel speeds faster avenues), accidents with horse (to force the horse to higher loads and work with food deficiency), the oversized loads, Insecurity (carts used in criminal acts, etc.).

Discussed above, we propose a management model should be based on the organization and distribution of income according to their obligations, they also organized into two categories: administrative and operating expenses. In the first should be organized and should include payroll and leases own activity and marketing efforts work and payments of financial obligations on the other hand, operating expenses must be related to logistics costs and vehicle maintenance costs.

\section{RECOMMENDATIONS}

When formalizing the processes, policies and tools oriented to the management and development of intellectual assets of the organization (in this case the District Department of Transportation Bogotá), with the aim of transforming the knowledge accumulated in value and benefits tangible to the organization and its stakeholders (other offices of the Mayor), we are talking about Knowledge Management.

We could say that the initial stage arose from the need of the District Department of Transportation to analyze the current situation and future projection VTA of resources and capacities of the city, designed to meet different scenarios, along with establishing a vision of the potential current and future (replacement) which will be based on the strategic development of the city traffic.

Given the importance of knowledge at a strategic level within the organization, there a next step that has generated the need for the development of a 'knowledge strategy', which forms the foundation for the success of the project in the organization. For this, being understood the context of the needs and projections set out in the strategy of knowledge and recognizing the degree of technological adaptability necessary for a development project.

Of course everything must start from the need for the wheelwrights to improve their working conditions and for this we examined the possibility technify your working tool, and this modernization is to change the binomial (wagon and horse) by a motorized means of transport base gasoline (motorcar) in addition to this is low power, high performance, reduce their travel time, increase their average speed, reduce operating costs, reduce maintenance costs and allow wheelwrights VTA, continue to make its core business, which at a later stage would be implementation.

In a globalized, knowledge management can be considered the organizational structure and culture that facilitates working together, sharing knowledge and information, physically and virtually, so that we are able to develop innovative products and services, new solutions and be more effective and effective.

Properly manage knowledge does not necessarily mean 
being more innovative, but it involves a solid foundation (in terms of culture, processes, policies and technologies) that can and should be used by the city as a lever for innovation and change

\section{CONCLUSIONS}

The model presented seeks to better explain the existing the way it performs the activity of the population derives its income from the use of animal-drawn vehicle, in addition to this, the model should also serve as input for the analysis retirement convenience or modernization of the working tool currently used wheelwrights (VTA).

With the above model can be analyzed as changes come to affect the activity of the population currently wheelwrights (VTA), this analysis can be performed independently of both the revenue of the activity, as the expenses of the same, with this you can develop strategies or mitigation and monitoring plans when making changes to the development of the activity.

Without proper knowledge management from top management enhanced with instruments suitable motivation and involvement, innovation becomes a process even more difficult, more distant and therefore much more expensive.

\section{ACKNOWLEDGMENT}

A large part of the changes made on the ground mentioned is due to the excellent leadership of those who have been part of the team of the Agreements between the District Department of Transportation and the University District. Special thanks to the General Conventions for trusting our talents for this project as well as its diverse team of advisers who supported us with information, and you should not forget our direct team tirelessly prepared the field logistics, collected and helped to classify the various sources of information and to Dr. Ingrid Campos who attended and supported the social management.

\section{REFERENCES}

[1] Convenio Interadministrativo 2009-1252 SDM-UD, Estructuración técnica, legal, financiera y social del proyecto retiro de vehículos de tracción animal - Elaboración de la caracterización socioeconómica de la población de carreteros (VTA) en la ciudad de Bogotá, D.C., incluidos escenarios propuestos de proyectos económicos viables y sostenibles que reemplacen y/o tecnifiquen el vehículo de tracción animal (VTA) - Fase uno, Parte 1, Bogotá - Colombia., 2009

[2] Convenio Interadministrativo 2009-1252 SDM-UD, Estructuración técnica, legal, financiera y social del proyecto retiro de vehículos de tracción animal - Elaboración de la caracterización socioeconómica de la población de carreteros (VTA) en la ciudad de Bogotá, D.C., incluidos escenarios propuestos de proyectos económicos viables y sostenibles que reemplacen y/o tecnifiquen el vehículo de tracción animal (VTA) - Fase uno, Parte 2, Bogotá - Colombia., 2009

[3] Convenio Interadministrativo 2009-1252 SDM-UD, Estructuración técnica, legal, financiera y social del proyecto retiro de vehículos de tracción animal - Elaboración de la caracterización socioeconómica de la población de carreteros (VTA) en la ciudad de Bogotá, D.C., incluidos escenarios propuestos de proyectos económicos viables y sostenibles que reemplacen y/o tecnifiquen el vehículo de tracción animal (VTA) - Fase uno, Parte 3, Bogotá - Colombia., 2009
[4] Fox, Robert ; Technological Change: Methods and Themes in the History of Technology, Routledge Group Edition, New York, 2009

[5] Crisman, Kevin J. \& Cohn, Arthur B; When horses walked on water: horse-powered ferries in nineteenth-century America, Smithsonian Institution Press, Whashington, 1998

[6] McShane, Clay \& Tarr, Joel A; The horse in the city: Living machines in the nineteenth Century; The Johns Hopkins University Press, Baltimore, 2007

[7] Lizet, Bernadette; La bête noire: à la recherche du cheval parfait; Editions MSH, Paris, 1989

[8] Mavré, Marcel; Attelages te attelées: un siècle d'utilisation du cheval de trait; Editions France Agricole, París, 2004

[9] J. J. Goñi. ¿Un innovador o muchos innovadores? [Online]. Available: http://www.gestiondelconocimiento.com/leer.php?id=339\&colaborador $=$ jjgoni

[10] N. Aramburu, Aprendizaje Organizativo, Tesis de Grado "Un Estudio del Aprendizaje Organizativo desde la Perspectiva del Cambio: Implicaciones Estratégicas y Organizativas.”, Universidad de Deusto, San Sebastián - España, 2000. Avalaible:

http://www.gestiondelconocimiento.com/documentos2/nekane/GCcam. PDF

[11] Alejandro Andrés Pavez Salazar, Tesis de Grado: "Modelo de implantación de Gestión del Conocimiento y Tecnologías de Información para la Generación de Ventajas Competitivas", Universidad Técnica Federico Santa María, Valparaíso - Chile, 2000. Avalaible:

http://www.gestiondelconocimiento.com/documentos2/apavez/zip/apave z.pdf

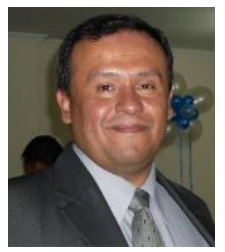

Ismael Fernando Sanchez Aparicio, Industrial Engineering and Project Management Specialist Engineering University District, consultant and business advisor, director Project "Technical, legal, financial and social withdrawal project drawn vehicles - Development of socioeconomic characterization wheelwrights population (VTA) in the city of Bogotá, DC, including proposed scenarios viable and sustainable economic projects that replace and / or technify animal-drawn vehicle (ATV) - Phase One ".

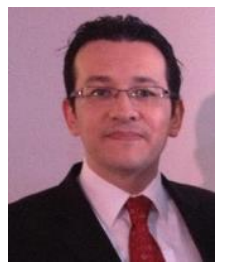

Oswaldo Alberto Romero Villalobos, Systems Engineer; Roads Design, Traffic and Transportation Specialist; Software Engineering Specialist, Master of Industrial Engineering, Professor and member of the Curriculum Project in Systems Engineering from the University District, Technical Director well as consultant and advisor to various agreements between the District Department of Transportation in Bogotá and the University District and municipalities in Colombia. 